INTERNATIONAL HIGHER EDUCATION NUMBER 65 FALL, 2011

Pages $10-12$

What International Students Think about US Higher Education

Patricia Chow

Patricia Chow is on the staff of the research and evaluation department, at the Institute of International Education, New York. E-mail: iieresearch@iie.org (for more information or a copy of the complete report).

According to the Open Doors Report on International Educational Exchange, in 2009/10, the United States hosted a record high of 691,000 international students from over 200 places of origin. While the United States does not practice a national strategy for the recruitment of international students, strategies implemented by other host destinations, both traditional and emerging, are creating a competitive global environment for recruiting top talent from around the world. In recent years, many host countries have ramped up efforts to internationalize their academic institutions, and students around the world are now choosing to study abroad in a much-wider variety of destinations.

To comprehend the concepts of potential international students around the world about US higher education-the Institute of International Education, in cooperation with the US Department of State's Bureau of Educational and Cultural Affairs and EducationUSA, conducted a series of perceptual and attitudinal surveys in 11 key original places. The following research questions are explored: Why do students from other countries wish to study in the United States? What course of study do they intend to pursue? Do they prefer the 
United States to other key destinations? What barriers do students face who wish to study in the United States? The Institute of International Education began surveying students in Vietnam and India in 2009; followed by Mexico, Thailand, and Hong Kong in spring 2010; Brazil, Germany, Turkey, and the United Kingdom during summer 2010; and Nigeria and South Africa in fall 2010. A total of 9,330 valid responses were received.

\section{PROFILE OF RESPONDENTS}

The majority of respondents worldwide (55\%) were female; 35 percent were current high school students; 40 percent were undergraduate degree students (or had completed an undergraduate degree but no graduate degree); 15 percent were graduate students; and 10 percent had another academic level, including nondegree students and students at two-year colleges or technical schools.

\section{Preferred Study Destinations}

The most popular first-choice destination chosen by respondents worldwide was the United States, with 75 percent of prospective study-abroad students listing the United States as their first-choice destination in an open-ended question. The United Kingdom was the next most popular first-choice destination, with 8 percent of the total, followed by Canada (5\%) and Australia (3\%).

The preferred destinations chosen by respondents reflect the existing patterns of global student mobility. Currently, the United States hosts 20 percent of the 3.3 million students worldwide who are pursuing higher education outside their home countries. The United Kingdom has the next-largest fraction, with 13 percent of the total, followed by France (8\%), Germany (7\%), China (7\%), 
Australia (7\%), Canada (4\%), and Japan (4\%) (Project Atlas, www.iie.org/projectatlas). While Spain does not figure among the top eight host destinations worldwide, it is a popular study-abroad destination for students from Latin America.

\section{IMPRESSIONS OF KEY HOST DESTINATIONS}

The majority of students rated the United States more positively than other potential destinations in most of the areas surveyed. This was expected given that the students were prospecting study in the United States; however, the magnitude of the preference was quite large in many cases. For example, over three-quarters $(76 \%)$ of respondents worldwide perceived the United States to have a wide range of schools and programs, as compared with 35 percent for the United Kingdom and 28 percent for Canada-the host destinations with the nexthighest percentages. Similarly, over three-quarters $(76 \%)$ of respondents worldwide also perceived the United States to have a high-quality higher education system, as compared with 50 percent for the United Kingdom, 33 percent for Canada, and 31 percent for Germany - the host destinations with the next-highest percentages. In addition, over two-thirds (69\%) of respondents worldwide felt that the United States welcomes international students, as compared with 42 percent for Canada, 34 percent for Australia, and 33 percent for the United Kingdom-the host destinations with the next-highest percentages.

The United States was also perceived to be a host destination with many scholarship opportunities and good student support services by over half of respondents (59\% and 57\%, respectively). This is a significantly higher 
proportion than the other host destinations received $(22 \%$ and $30 \%$, respectively, for Canada-the next highest). However, 60 percent of respondents worldwide felt that tuition in the United States is expensive-the highest among all of the host destinations. Only the United Kingdom was roughly comparable, with 51 percent. In addition, 49 percent of respondents felt that the United States had difficult or complex student visa procedures and also the highest of any of the host destinations. Only 23 percent of respondents felt that the United Kingdom had difficult or complex student visa procedures-the host destination with the next-highest percentage. The United Kingdom was rated a host destination with a high cost of living by the highest number of respondents worldwide, at 54 percent, followed by the United States with 45 percent, Japan with 34 percent, and France with 33 percent.

With regard to language, Japan was rated a host destination with a significant language barrier by the highest number of respondents worldwide, at 97 percent; followed by Germany and France, with 56 percent each.

The results of the survey indicate that despite not having any national policies designed to attract students from other countries, the United States remains well-positioned in the international student marketplace-with various "pull factors" (causing students to choose a specific destination over others) attracting students to the United States. Among these, the high quality and diverse range of US higher education institutions predominate. The perception that the United States is a welcoming country for international students is also significant. However, "anti-push factors" (roadblocks for students who otherwise might wish to study internationally) also exist, with cost 
predominating. The difficulty of obtaining a student visa is also a negative factor, although it is not perceived to be as great a barrier as cost and varies by country. 